\title{
Desired Qualification of Graduates of the Faculty of Industrial Technology
}

\author{
Nat Praseeratasange, Nathapakorn Juntapidta, Dusit Uthitsunthorn
}

Faculty of Industrial Technology, Buriram Rajabhat University, Buriram, Thailand

Email address:

nat.ps@bru.ac.th (N. Praseeratasange), natapakon.jt@bru.ac.th (N. Juntapidta), dusit.ut@bru.ac.th (D. Uthitsunthorn)

\section{To cite this article:}

Nat Praseeratasange, Nathapakorn Juntapidta, Dusit Uthitsunthorn. Desired Qualification of Graduates of the Faculty of Industrial Technology. Science Journal of Education. Vol. 5, No. 4, 2017, pp. 129-135. doi: 10.11648/j.sjedu.20170504.11

Received: March 31, 2017; Accepted: May 2, 2017; Published: May 4, 2017

\begin{abstract}
The purpose of this research was to study the desirable qualifications of graduates. The participants were graduated bachelor's degree from the faculty of Industrial Technology, Buriram Rajabhat University in academic year 2015-2016. The result showed that the highest satisfactions were the morality, ethics, diligence, honesty, patience, and professional skills $(\bar{Y} 5=4.80)$. It was followed by the creative thinking and acquiring knowledge $(\bar{Y} 6=4.76)$. Then, the satisfaction on the knowledge application to develop their local was at the least level $(\overline{\mathrm{Y}} 4=4.57)$. However, when the means of satisfaction of graduates for the desirable qualifications were compared as topic level, it was found that the p-value was 0.041 , which was less than the statistical significance level that was set at 0.05 . Therefore, the differences in each topic of desirable characteristics of graduates affected the satisfaction level of desirable characteristics of graduates of the faculty of Industrial Technology. The faculty of Industrial Technology had to develop the desirable characteristics of graduates by applying the knowledge to develop their own local. Because of this, the employers will be satisfied by the graduates' desirable characteristics who graduated in the bachelor's degree from the faculty of Industrial Technology, Buriram Rajabhat University.
\end{abstract}

Keywords: Graduates, Desirable Qualifications, Employers

\section{Introduction}

The faculty of Industrial Technology in Buriram Rajabhat University, Buriram Province, situated at the Northeast region of Thailand, consists of 6 departments; industrial design, construction technology, architecture technology, electronics technology, technology of ceramics and industrial management. Its mission is to produce the manpower to support the expansion of the small and medium enterprises (SME) of an industrial sector in the state policy, since the satisfactory is needed for manpower both of the local level to the national level. This Faculty is a manufacturer of graduates who graduated bachelor's degree of industrial technology to fill the needs of local community. The graduates applied their knowledge to develop society and country. However, they have a job in their fields and other fields. The learning achievement of the graduates was also measured after they graduated for one year by measuring the percentage of the graduates with unemployment. This research aimed to develop the quality of graduates set from labor markets. The employers requested activation, responsibility, knowledge and abilities for working and the social personality from the graduates. Therefore, the researcher studied the graduates working ability and evaluated the desired qualification and characteristics for graduates' working. The result of this research was used to improve and to develop the teaching method and to improve the graduates' ability provided by universities for the labor market. The human resource management will support the public sector of economic development in the country.

It was necessary to open the curriculum of industrial technology in universities to support the policies of the country and requirements of manpower. It also had the motivation of the increasing of employment and labor needs as well [1]. Therefore, all of them have an inspiration to generate students into working with companies after graduating. In addition, the characteristics of graduates that needed by companies were having appropriate academic knowledge and morality and ethics in occupation. Nowadays, graduates also have to develop their occupational skill in order to have a good opportunity to work with companies. Moreover, the industry also developed the human resource for competing with others as it is important 
for the business to grow up in a country. In addition, they have to receive the highest quality of personnel from the universities in order to work. The faculty can train the students for the best of knowledge, morality, experience, language and prepared them to get into working market after graduation. This principal of industrial technology education will be an achievement. However, the development of the students of the faculty to prepare in a various field is also extremely necessary. The characteristic of a curriculum in each qualification level ensures the effectiveness of universities in order to generate for achievement [2]-[3].

The objective of this research was to survey the desirable characteristic of graduates for employers about knowledge, morality, and language. The items were shown in below section.

\section{Research Methodology}

This study was a survey research which investigated the desirable characteristics of the graduates who graduated bachelor's degree from the faculty of Industrial Technology, Buriram Rajabhat University in the academic year 2015 - 2016. The instrument of this study was questionnaire. The demographic data was used to collect information on the employees.

\subsection{Population and Samples}

The samples of this study were 109 companies. They had to

Independent Variables

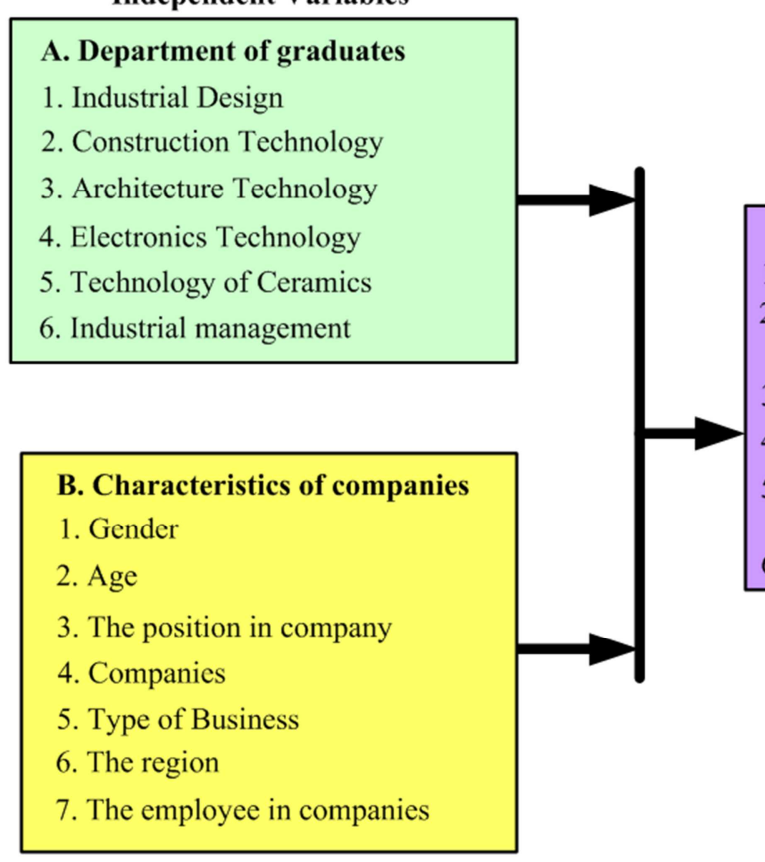

complete the questionnaires in order to survey the characteristics of graduates from 6 departments in each employer's option. The results were analyzed and compared the satisfaction of the main point in work.

\subsection{Research Framework and Variables}

The researcher studied the desirable characteristics of graduates as shown in Figure 1. This research instrument was questionnaire adapted from the survey of employability in workplace. It was divided into 3 sections. Section A consisted of the demographic questions. Section B was included the fields of theirs studies in departments. Section $\mathrm{C}$ consisted of the questions which measured the employers' satisfaction. The elaborations were as followed [4]-[7].

Section A: The Departments of Graduated.

Section B: General Information of Respondents.

Section C: The Needs of Desirable Characteristics of Graduates;

- Abilities in academic and professional skills.

- Use of language, foreign language, and information technology.

- Understanding and realization of the value of local.

- Application of knowledge to develop their own local.

- Having morality, ethics, diligence, honesty, patience, and professional skills.

- Having creative thinking and acquiring knowledge.

Figure 1. Research framework.

\subsection{Instrument Used in the Data Collection}

The research instrument was questionnaire which was adapted from psychosocial working condition questionnaires of [8]-[9] which were used for assessing characteristics of graduates. There are 4 processes of data analysis;

\section{Dependent Variables}

C. Desired qualification of graduates

1.There are academic and professional ability.

2.Use of language, foreign languages and information technology.

3.Understanding and realization of the value of the local.

4. Application of knowledge to develop their own local.

5. Having moral ethics, patience, diligence, honesty and professional skills.

6. Having creative thinking and acquiring knowledge.

\subsubsection{Questionnaire Design}

To investigate the completeness and relevancy of the answers in the questionnaire.

\subsubsection{Rating Scale of Questionnaire}

The questionnaires measured with 5 level rating scale, as 5 
= very much satisfaction to $1=$ least satisfaction. It analyzed the graduate's characteristic needed by the companies as shown in Table 1.

Table 1. The 5 level of response scale.

\begin{tabular}{ll}
\hline Satisfaction & Level \\
\hline Very much & 5 \\
Much & 4 \\
Moderate & 3 \\
Less & 2 \\
Least & 1 \\
\hline
\end{tabular}

\subsubsection{Data Analysis}

The objective of this study was to investigate the relationship of the desired qualification of graduates. The respondents were selected based on the convenience sampling, then the descriptive statistics used to analyze the data were frequency, percentage, mean, standard deviation, and ANOVA by using the Statistical for Social Science (SPSS) program. The statistical results were presented on the table and the employer's satisfaction was discussed. The means of satisfaction were analyzed and compared with the functions of satisfying into 5 boundary condition in [10]-[12], as shown in Table 2.

Table 2. The explanation of functions which satisfy.

\begin{tabular}{ll}
\hline Mean & Level of satisfaction \\
\hline $1.00-1.49$ & Least \\
$1.50-2.49$ & Low \\
$2.50-3.49$ & Moderate \\
$3.50-4.49$ & Much \\
$4.50-5.00$ & High \\
\hline
\end{tabular}

\subsubsection{The Statistic Analysis}

The data from the questionnaires was analyzed by using statistics as the followed;

Part 1: General information of respondents was analyzed by the frequency and percentage.

Part 2: The level of satisfaction of employers was analyzed by using the mean and standard deviation.

Part 3: The relationship of 6 items that represented the characteristics of graduates was analyzed by using the randomized complete block design (RBD) with the significance level at 0.05 . If curriculums affected the level of desirable characteristics of graduates, a researcher will use the method of Duncan's multiple range test for comparing the average of satisfaction on desirable characteristics of graduates in each item and bring the results to develop the curriculums.

Part 4: The recommendation of desirable graduates' characteristics from companies.

\subsection{Hypothesis Testing}

Ho: $\tau 1=\tau 2=\tau 3=\tau 4=\tau 5=\tau 6=0$

H1: $\tau i \neq 0$ the least 1 value when $i=1,2,3,4,5,6$

when the significance level at 0.05

Ho: $\beta 1=\beta 2=\beta 3=\beta 4=\beta 5=\beta 6=0$
$\mathrm{H} 1: \beta \mathrm{j} \neq 0$ the least 1 value when $\mathrm{j}=1,2,3,4,5,6$ when the significance level at 0.05

\section{Explanation and Results}

The collected data was the desirable qualifications of graduates from the faculty of Industrial Technology. The instrument used in this study was the questionnaire. The purpose of this study was to survey the desirable characteristics of graduates from employers' opinion. It identified the variables and the independent's factors of requirements from an employee in section $\mathrm{A}$ and section $\mathrm{B}$. Then, in section $\mathrm{C}$ was the dependent factor. The total populations were 109 respondents who returned the questionnaire. This study measured the desired qualification of graduates from the companies.

The percentage of the graduates from the 6 departments, as shown in Table 3, included: the Department of Industrial Management (55.04\%), Electronics Technology (13.76\%), Construction Technology (11.00\%), Industrial Design (7.33\%), and the Department of Architecture Technology and Technology of Ceramics (6.42\%).

Table 3. The departments of graduates.

\begin{tabular}{lll}
\hline Department of graduates & $\mathbf{N}=\mathbf{1 0 9}$ & (\%) Percentage \\
\hline Industrial Design & 8 & 7.33 \\
Construction Technology & 12 & 11.00 \\
Architecture Technology & 7 & 6.42 \\
Electronics Technology & 15 & 13.76 \\
Technology of Ceramics & 7 & 6.42 \\
Industrial management & 60 & 55.04 \\
\hline
\end{tabular}

Table 4. The percentage of general information.

\begin{tabular}{|c|c|c|}
\hline Demographic Factors & $N=109$ & (\%) Percentage \\
\hline \multicolumn{3}{|l|}{ 1. Gender } \\
\hline Male & 83 & 76.14 \\
\hline Female & 26 & 23.85 \\
\hline \multicolumn{3}{|l|}{ 2. Age } \\
\hline $31-40$ & 59 & 54.12 \\
\hline $41-50$ & 50 & 45.87 \\
\hline \multicolumn{3}{|l|}{ 3. The Position in Company } \\
\hline Head Office & 43 & 39.44 \\
\hline Department Manager & 36 & 33.02 \\
\hline Employee & 30 & 27.52 \\
\hline \multicolumn{3}{|l|}{ 4. Companies } \\
\hline A Private Company & 93 & 85.32 \\
\hline State Enterprise & 13 & 10.91 \\
\hline Government & 3 & 2.75 \\
\hline \multicolumn{3}{|l|}{ 5. Type of Business } \\
\hline Design and Decoration. & 37 & 33.94 \\
\hline Computer & 32 & 29.35 \\
\hline Public Assistants & 3 & 2.75 \\
\hline \multicolumn{3}{|l|}{ 6. The Region } \\
\hline Northeast Region & 65 & 59.63 \\
\hline Central Region & 31 & 28.44 \\
\hline
\end{tabular}




\begin{tabular}{cll}
\hline Demographic Factors & $\mathbf{N}=\mathbf{1 0 9}$ & $(\%)$ Percentage \\
\hline Western Region & 3 & 2.75 \\
$\begin{array}{c}\text { 7. The Employee in Companies } \\
<100\end{array}$ & 96 & \\
$100-300$ & 13 & 11.92 \\
\hline
\end{tabular}

The percentage and sample size of general information represented the general information of respondents as shown in Table 4. Most of the respondents were male (76.14\%), and female $(23.85 \%)$. The age of $31-40$ years old $(54.12 \%)$, followed by $41-50$ years old $(45.87 \%)$. The position in the company of respondents were the head of office $(39.44 \%)$, department manager (33.02\%) and employee (27.52\%), respectively. Most of the respondents were in a private company $(85.32 \%)$, the state enterprise $(11.91 \%)$, and the government $(2.75 \%)$.

Table 5. The average satisfaction of graduates.

\begin{tabular}{|c|c|c|c|}
\hline Demographic Factors & Mean & S.D. & Level of satisfaction \\
\hline \multicolumn{4}{|c|}{ There are academic and professional ability. } \\
\hline 1. Academic knowledge & 4.94 & 0.22 & \\
\hline 2. Professional ability. & 4.77 & 0.42 & \\
\hline 3. Knowledge in the work unit & 4.84 & 0.15 & \\
\hline 4. The responsibility & 4.53 & 0.23 & \\
\hline 5. Operating methods & 4.97 & 0.52 & \\
\hline \multirow[t]{2}{*}{ 6. Application of knowledge } & 4.33 & 0.28 & \\
\hline & $\bar{Y} 1=4.73$ & 0.32 & High \\
\hline \multicolumn{4}{|c|}{ Use of language, foreign languages and information technology. } \\
\hline 1. Using Technology & 4.76 & 0.42 & \\
\hline 2. Communication & 4.83 & 0.23 & \\
\hline 3. Statistic & 4.81 & 0.38 & \\
\hline \multirow[t]{2}{*}{ 4. Document Storage } & 4.45 & 0.50 & \\
\hline & $\overline{\mathrm{Y}} 2=4.71$ & 0.38 & High \\
\hline 1. A local academic & 4.47 & 0.50 & \\
\hline 2. Local benefits & 4.72 & 0.44 & \\
\hline \multirow[t]{2}{*}{ 3. Local procedures } & 4.87 & 0.33 & \\
\hline & $\bar{Y} 3=4.68$ & 0.42 & High \\
\hline \multicolumn{4}{|c|}{ Application of knowledge to develop their own local. } \\
\hline 1. Using local knowledge & 4.50 & 0.50 & \\
\hline 2. The local application & 4.76 & 0.42 & \\
\hline \multirow[t]{2}{*}{ 3. The local creativity } & 4.45 & 0.50 & \\
\hline & $\overline{\mathrm{Y}} 4=4.57$ & 0.47 & High \\
\hline \multicolumn{4}{|c|}{ Have moral ethics, patience, diligence, honesty and professional skills. } \\
\hline 1. To be a Honest & 4.87 & 0.33 & \\
\hline 2. Social rules & 4.98 & 0.13 & \\
\hline 3. Punctual & 4.56 & 0.49 & \\
\hline 4. Sacrificing & 4.98 & 0.32 & \\
\hline \multirow[t]{2}{*}{ 7. The moral } & 4.76 & 0.42 & \\
\hline & $\bar{Y} 5=4.80$ & 0.36 & High \\
\hline \multicolumn{4}{|c|}{ Have creative thinking and acquiring knowledge. } \\
\hline 1. The task sequence & 4.96 & 0.18 & \\
\hline 2. Analytical thinking & 4.79 & 0.40 & \\
\hline 3. Learn the job & 4.76 & 0.43 & \\
\hline 4. The vision & 4.70 & 0.46 & \\
\hline \multirow[t]{2}{*}{ 5. Problem-solving } & 4.61 & 0.48 & \\
\hline & $\overline{\mathrm{Y}} 6=4.76$ & 0.39 & High \\
\hline The total of satisfaction graduates & 4.70 & 0.39 & High \\
\hline
\end{tabular}

Besides, the types of respondents' business were design and decoration (33.94\%), computer (29.35\%) and public assistant $(2.75 \%)$. The locations of respondents' business were in the northeast region $(59.63 \%)$, central region $(28.44 \%)$ and western region $(2.75 \%)$. In addition, the sizes of the respondents' business were under 100 employees (88.07\%) and more than 100-300 employees (11.92\%).
In Table 5, the desirable qualifications of graduates were presented. The participants were the employers who completed the questionnaires from the workplace. It was divided into 6 items of satisfaction. The result suggested that the fifth item which consisted of the moral, the ethics, the patience, the diligence, the honesty and the professional skills were at the highest average level $(\overline{\mathrm{Y}} 5=4.80)$. When 
considered each item, the researchers found that both sacrificing and social rules were at the highest average level (4.98), and the least average level at 4.56 was be punctual. Then, the sixth item which represented the creative thinking and acquiring knowledge continuously was at the high level $(\overline{\mathrm{Y}} 6=4.76)$. When the researchers considered each item, it was found that the part of task sequence was at high satisfaction level with the average of 4.96, and the problem-solving was at the lowest satisfaction level with the average of 4.61. The result also showed that the first item which consisted of the academic and professional ability of desired qualification of graduates was at high level ( $\bar{Y} 1=4.73$ ). Considering each item, the part of operating methods was at high satisfaction level with the average of 4.97, and the application of knowledge was at much satisfaction level with the average of 4.33. Using language, foreign languages and information technology which were included in the second item were at high level ( $\bar{Y} 2=4.71$ ). The result of considering each item showed that the part of communication was at high satisfaction level with the average of 4.83 and the document storage was at much satisfaction level with the average of 4.45 . Then, the third item which included the average of the understanding and realization of the value of the local was at high average level ( $\bar{Y} 3=4.68$ ). Considering each item, the part of local procedures was at high satisfaction level with the average of 4.87 and the local academic was at much satisfaction level with the average of 4.47. Finally, the application of knowledge to develop their own local which was included in the forth item was at high average level $(\bar{Y} 4=4.57)$. The result of each item revealed that the subject of the local application was at high satisfaction level with the average of 4.76 and the local creativity was at much satisfaction level with the average of 4.45 .

Table 6. The summation of desired qualification of graduates consisted of 6 departments.

\begin{tabular}{|c|c|c|c|c|c|c|c|}
\hline \multirow[b]{2}{*}{ Demographic Factors } & \multicolumn{7}{|c|}{ Department of } \\
\hline & $\begin{array}{l}\text { Industrial } \\
\text { Design }\end{array}$ & $\begin{array}{l}\text { Construction } \\
\text { Technology }\end{array}$ & $\begin{array}{l}\text { Architecture } \\
\text { Technology }\end{array}$ & $\begin{array}{l}\text { Electronics } \\
\text { Technology }\end{array}$ & $\begin{array}{l}\text { Technology } \\
\text { of Ceramics }\end{array}$ & $\begin{array}{l}\text { Industrial } \\
\text { Management }\end{array}$ & Mean \\
\hline 1. There are academic and professional ability. & 4.70 & 4.83 & 4.72 & 4.69 & 4.75 & 4.72 & 4.73 \\
\hline $\begin{array}{l}\text { 2. Use of language, foreign languages and information } \\
\text { technology. }\end{array}$ & 4.71 & 4.70 & 4.69 & 4.71 & 4.72 & 4.76 & 4.71 \\
\hline 3. Understanding and realization of the value of the local. & 4.57 & 4.69 & 4.71 & 4.47 & 4.79 & 4.85 & 4.68 \\
\hline 4. Application of knowledge to develop their own local. & 4.75 & 4.77 & 4.40 & 4.47 & 4.51 & 4.54 & 4.57 \\
\hline $\begin{array}{l}\text { 5. Having moral ethics, patience, diligence, honesty and } \\
\text { professional skills. }\end{array}$ & 4.81 & 4.89 & 4.86 & 4.76 & 4.83 & 4.69 & 4.80 \\
\hline $\begin{array}{l}\text { 6. Having creative thinking and acquiring knowledge } \\
\text { continuously. }\end{array}$ & 4.85 & 4.78 & 4.79 & 4.81 & 4.64 & 4.74 & 4.76 \\
\hline Mean & 4.73 & 4.75 & 4.69 & 4.65 & 4.70 & 4.71 & - \\
\hline
\end{tabular}

The result revealed that the employers satisfied with the graduates at high level (4.70). Moreover, according to Table 6, the Department of Construction Technology received the highest satisfaction level at the average of 4.75 , followed by the Industrial Design (4.73), the Industrial Management (4.71), the Technology Ceramics (4.70), Architecture Technology (4.69), and the Electronic Department of Technology (4.65), respectively.

The graduates of the Department of Architecture Technology had the application of the knowledge to develop their own local at much satisfied level (4.40) which was considered to be at minimum level while the Department of Construction Technology had the moral, the ethics, the patience, the diligence, the honesty and the professional skills at the maximum level of high satisfaction level (4.89). However, it can be summarized that the employers satisfied with the desired qualification as shown in Table 6 .

\section{Discussion}

This section examined the relationship between the 6 items which represented the desired characteristics of graduates and the fields of each department that were different in the satisfaction of desired qualifications of graduates in each course. The researchers used Randomize Complete Block Design (RBD) in testing; and if the desired qualifications of graduates were at different level, the researchers used a method of Duncan's multiple range test to compare the satisfaction level in each item.

\subsection{The Results of the Hypothesis Test}

This study used Two-way ANOVA to analyze the variance response versus fields as shown in Table 7 [13]-[14].

Table 7. The Block-Design Tests.

\begin{tabular}{llllll}
\hline Source & DF & SS & MS & F & P \\
\hline Treatment & 5 & 0.007347 & 0.0014694 & 0.11 & 0.989 \\
Block & 5 & 0.185381 & 0.0370761 & 2.76 & 0.041 \\
Error & 25 & 0.336369 & 0.0134548 & - & - \\
Total & 35 & 0.529097 & - & - & - \\
\hline
\end{tabular}

$\mathrm{S}=0.1160 \mathrm{R}-\mathrm{Sq}=36.43 \% \mathrm{R}-\mathrm{Sq}(\operatorname{adj})=11.00 \%$

The $\mathrm{p}$-value was $=0.041$, which was less than the significance level at 0.05 , therefore, the Ho was rejected. This means there was differences among the desirable characteristics of graduates in each item which affected the satisfaction with the significance level of 0.05 .

\subsection{Duncan's Multiple Range Testing}

Duncan testing was used to compare the means value of multiple variables, where, in each set, means have been found 
not to be significantly different from one another in the desirable features. They were calculated from series of values corresponding to a specific set of pair comparisons as followed [15]-[16].

Step 1: Arranging the average characteristics of the graduates from the least to the most.

$$
\begin{aligned}
& \overline{\mathrm{Y}} 4=4.57 \\
& \overline{\mathrm{Y}} 3=4.68 \\
& \overline{\mathrm{Y}} 2=4.71 \\
& \overline{\mathrm{Y}} 1=4.73 \\
& \overline{\mathrm{Y}} 6=4.76 \\
& \overline{\mathrm{Y}} 5=4.80
\end{aligned}
$$

Step 2: Finding standard error value in equation (1).

$$
\begin{gathered}
\mathrm{S}_{\mathrm{yi}}=\sqrt{\frac{\mathrm{MSE}}{\mathrm{n}}} \\
=\sqrt{\frac{0.013}{6}}=0.046
\end{gathered}
$$

Step 3: Consult the table of significant ranges for Duncan's Multiple Range Test to find the critical value in equation (2)-(6) of $r \alpha(p, f)$ where $p=2,3,4,5,6$

$$
\begin{aligned}
& \mathrm{r} \alpha(\mathrm{p}, \mathrm{f})=\mathrm{r} 0.05(2,25)=2.92 \\
& \mathrm{r} \alpha(\mathrm{p}, \mathrm{f})=\mathrm{r} 0.05(3,25)=3.07 \\
& \mathrm{r} \alpha(\mathrm{p}, \mathrm{f})=\mathrm{r} 0.05(4,25)=3.15 \\
& \mathrm{r} \alpha(\mathrm{p}, \mathrm{f})=\mathrm{r} 0.05(5,25)=3.22 \\
& \mathrm{r} \alpha(\mathrm{p}, \mathrm{f})=\mathrm{r} 0.05(6,25)=3.27
\end{aligned}
$$

Step 4: Tranform the value to calculate the least significant range of $r \alpha(p, f)$ to $R p$ in equation (7)-(11).

$$
\begin{aligned}
& \mathrm{R} 2=2.92 \times 0.046=0.134 \\
& \mathrm{R} 3=3.07 \times 0.046=0.141 \\
& \mathrm{R} 4=3.15 \times 0.046=0.144 \\
& \mathrm{R} 5=3.22 \times 0.046=0.148 \\
& \mathrm{R} 6=3.27 \times 0.046=0.150
\end{aligned}
$$

Step 5: Test the difference of each pair in equation (12)-(26).

$\mu 5$ compared $\mu 4$ is $\overline{\mathrm{Y}} 5-\overline{\mathrm{Y}} 4=4.80-4.57$

$$
=0.23>\mathrm{R} 6=0.150 \text { Difference }
$$

$\mu 5$ compared $\mu 3$ is $\bar{Y} 5-\bar{Y} 3=4.80-4.68$

$$
=0.12<\mathrm{R} 5=0.148 \text { Non-difference }
$$

$\mu 5$ compared $\mu 2$ is $\overline{\mathrm{Y}} 5-\overline{\mathrm{Y}} 2=4.80-4.71$

$$
=0.09<\mathrm{R} 4=0.144 \text { Non-difference }
$$

$\mu 5$ compared $\mu 1$ is $\overline{\mathrm{Y}} 5-\overline{\mathrm{Y}} 1=4.80-4.73$

$$
=0.07<\mathrm{R} 3=0.141 \text { Non-difference }
$$

$\mu 5$ compared $\mu 6$ is $\overline{\mathrm{Y}} 5-\overline{\mathrm{Y}} 6=4.80-4.76$

$$
=0.04<\mathrm{R} 2=0.134 \text { Non-difference }
$$

$\mu 6$ compared $\mu 4$ is $\overline{\mathrm{Y}} 6-\overline{\mathrm{Y}} 4=4.76-4.57$

$$
=0.19>\mathrm{R} 5=0.148 \text { Difference }
$$

$\mu 6$ compared $\mu 3$ is $\overline{\mathrm{Y}} 6-\overline{\mathrm{Y}} 3=4.76-4.68$

$$
=0.08<\mathrm{R} 4=0.144 \text { Non-difference }
$$

$\mu 6$ compared $\mu 2$ is $\overline{\mathrm{Y}} 6-\overline{\mathrm{Y}} 2=4.76-4.71$

$$
=0.05<\mathrm{R} 3=0.141 \text { Non-difference }
$$

$\mu 6$ compared $\mu 1$ is $\overline{\mathrm{Y}} 6-\overline{\mathrm{Y}} 1=4.76-4.73$

$$
=0.03<\mathrm{R} 2=0.134 \text { Non-difference }
$$

$\mu 1$ compared $\mu 4$ is $\overline{\mathrm{Y}} 1-\overline{\mathrm{Y}} 4=4.73-4.57$

$$
=0.16>\mathrm{R} 4=0.144 \text { Difference }
$$

$\mu 1$ compared $\mu 3$ is $\overline{\mathrm{Y}} 1-\overline{\mathrm{Y}} 3=4.73-4.68$

$$
=0.05<\mathrm{R} 3=0.141 \text { Non-difference }
$$

$\mu 1$ compared $\mu 2$ is $\overline{\mathrm{Y}} 1-\overline{\mathrm{Y}} 2=4.73-4.71$

$$
=0.02<\mathrm{R} 2=0.134 \text { Non-difference }
$$

$\mu 2$ compared $\mu 4$ is $\bar{Y} 2-\bar{Y} 4=4.71-4.57$

$$
=0.14<\mathrm{R} 3=0.141 \text { Non-difference }
$$

$\mu 2$ compared $\mu 3$ is $\bar{Y} 2-\bar{Y} 3=4.71-4.68$

$$
=0.03<\mathrm{R} 2=0.134 \text { Non-difference }
$$

$\mu 3$ compared $\mu 4$ is $\overline{\mathrm{Y}} 3-\overline{\mathrm{Y}} 4=4.68-4.57$

$$
=0.11<\mathrm{R} 3=0.134 \text { Non-difference }
$$

\subsection{Summary of the Results}

The satisfaction of the desirable features of the graduate under item 5 to item 4 , item 6 to item 4 and item 1 to item 4 were different, the others were non-different.

$$
\overline{\overline{\bar{Y}} 2 \overline{\overline{\mathrm{Y}}} 4 \overline{\bar{Y}} 3 \text { then }} \overline{\overline{\bar{Y}} 1 \overline{\overline{\mathrm{Y}} 2 \overline{\bar{Y}} 5 \overline{\bar{Y}} 3 \overline{\mathrm{Y}} 6}}
$$

Therefore, the result can be concluded that the desirable characteristics of graduates in the Faculty of Industrial Technology should be developed in item 4, to apply 
knowledge in development their community, which the employers will be satisfied.

\section{Conclusion}

The responders in this study indicated satisfaction with the adequacy of the industrial programs. There were problems with the industrial education and preparation for work in industrial technology. However, it can be concluded that the desirable characteristics of graduates in the Faculty of Industrial Technology should be developed in the item 4 from Table 5, as it received the minimum level in the application of the knowledge, the document storage, the local academic and the local creativity, respectively. However, in item 4, they have to apply knowledge to develop their own community which the employers will be satisfied. Moreover, they should have some experiences in their studies settings in the field of industry, which may have assisted them in clearer understanding in order to prepare themselves for the reality of the workplace. In addition, the satisfaction level, according to the graduates' report, was at the lowest level in the Department of Architecture Technology in item 4. As a consequence, the lecturers of the department need to integrate the learning requirements from employers with theory and skill development in the university environments and a training of human resources. Hence, the graduates will finally be supported to receive the advantages on the quality of learning and employers' satisfaction.

\section{References}

[1] H. Jalal, "Examining the Effects of Employee Empowerment, Teamwork, and Employee Training on Organizational Commitment," Social and Behavioral Sciences, Vol. 229, pp. 298-306, August, 2016.

[2] R. S. Munir and R. A. Rahman, "Determining dimension of job satisfaction using factor analysis economics and finance," Vol. 37, pp. 488-496, 2016.

[3] M. E. Menon, N. Pashourtidou, A. Polycarpou and P. Pashardes, 'Students' expectations about earnings and employment and the experience of recent university graduates: Evidence from Cyprus," International Journal of Educational Development, Vol. 32, Issue 6, pp. 805-813, November, 2012.

[4] B. Phongphanich, P. Ke-chung, N. Changkid and S. Chobtrong, "Students' characteristics needs by companies according to cooperative education: the case of muang district at suratthani province, Thailand," International Journal on New Trends in Education and Their Implications, Vol. 6, Issue 2, pp. 81-91, 2015.

[5] M. E. Menon, N. Pashourtidou, A. Polycarpou and P. Pashardes, 'Students' expectations about earnings and employment and the experience of recent university graduates: evidence from Cyprus," International Journal of Educational Development, Vol. 32, Issue 6, pp. 805-813, November, 2012.

[6] A. Ramli, R. Nawawi and M. P. P. Chun, "Employees' perception of employability skills needed in to days workforce among physiotherapy graduates," Social and Behavioral Sciences, Vol. 7, pp. 455-463, 2010.

[7] M. Coetzee and N. Harry, "Emotional intelligence as a predictor of employees' career adaptability," Journal of Vocational Behavior, Vol. 84, Issue 1, pp. 90-97, February, 2014.

[8] K. M. Wildey, P. Kenny, G. Parmenter and J. Hal, "Educational preparation for clinical nursing: The satisfaction of students and new graduates from two Australian universities," Nurse Education Today, Vol. 34, pp. 648-654, April, 2014.

[9] Y. H. Al-Dlaigan, S. F. AlBarakati, F. Al-Habeeb and M. Al-Hulaily, "Career characteristics and postgraduate education of female dentist graduates of the college of dentistry at king saud university, Saudi Arabia," The Saudi Dental Journal, Vol. 24, Issue 1, pp. 29-34, 2012.

[10] S. M. Tharikh, C. Y. Ying, Z. M. Saad and K. Sukumaran, "Managing job attitudes: The roles of job satisfaction and organizational commitment on organizational citizenship behaviors," Economics and Finance, Vol. 35, pp. 604-611, 2016.

[11] T. Yamane, Statistics an introductory analysis, 2nd ed, New York: Harper and Row, 1967.

[12] B. J. winer, Statistical principles in experimental design, 2 nd ed., Mcgraw-hill, 1971.

[13] C. Tadeusz and K. Sanpei, Block designs: A Randomization approach, Volume I: Analysis. Lecture Notes in Statistics, New York: Springer-Verlag, 2000.

[14] M. B. Wilk, "The Randomization Analysis of a Generalized Randomized Block Design," Biometrics, pp. 70-79. June, 1955.

[15] J. P. Shaffer, "A semi-Bayesian study of Duncan's Bayesian multiple comparison procedure," Journal of Statistical Planning and Inference, pp. 197-213, 1999.

[16] Duncan, D. B. (1955). "Multiple range and multiple F tests". Biometrics, Vol. 11, pp. 1-42. 